Check for updates

Cite this: Chem. Sci., 2017, 8, 5454

\title{
Norborn-2-en-7-ones as physiologically-triggered carbon monoxide-releasing prodrugs $\dagger$
}

\author{
Jui Thiang Brian Kueh, (D) a Nathan J. Stanley, (D) ${ }^{a}$ Russell J. Hewitt, ${ }^{a}$ Laura M. Woods, ${ }^{a}$ \\ Lesley Larsen, ${ }^{a}$ Joanne C. Harrison, (DD ${ }^{b}$ David Rennison, ${ }^{c}$ Margaret A. Brimble, (iD ${ }^{c}$ \\ Ivan A. Sammut (D) ab and David S. Larsen (iD *a
}

\begin{abstract}
A prodrug strategy for the release of the gasotransmitter $\mathrm{CO}$ at physiological $\mathrm{pH}$, based upon 3a-bromonorborn-2-en-7-one Diels-Alder cycloadducts of 2-bromomaleimides and 2,5-dimethyl-3,4diphenylcyclopentadienone has been developed. Examples possessing protonated amine and diamine groups showed good water solubility and thermal stability. Half-lives for CO-release in TRIS-sucrose buffer at $\mathrm{pH} 7.4$ ranged from 19 to $75 \mathrm{~min}$ at $37^{\circ} \mathrm{C}$ and 31 to $32 \mathrm{~h}$ at $4{ }^{\circ} \mathrm{C}$. Bioavailability in rats was demonstrated by oral gavage and oCOm-21 showed a dose dependent vasorelaxant effect in precontracted rat aortic rings with an $\mathrm{EC}_{50}$ of $1.6 \pm 0.9 \mu \mathrm{M}$. Increased intracellular $\mathrm{CO}$ levels following oCOm-21 exposure were confirmed using a $\mathrm{CO}$ specific fluorescent probe.
\end{abstract}

Received 13th April 2017 Accepted 27th May 2017

DOI: $10.1039 / \mathrm{c} 7 \mathrm{sc} 01647 f$

rsc.li/chemical-science approval for the application of low dose CO gas in a range of clinical application trials such as CO gas delivery by inhalation in heart valve replacement surgery ${ }^{13}$ and in renal transplant procedure recipients. ${ }^{14}$ Inhalation of CO (100-125 ppm) in chronic obstructive pulmonary disease (COPD) patients, reduced sputum neutrophils and improved bronchial responsiveness. ${ }^{15}$ In renal transplant procedures low dose CO gas during surgery improves post-transplant kidney function. ${ }^{\mathbf{1 6}}$ However, the difficulty of controlling gas delivery in a clinical setting, combined with the hazardous consequences of any gas leak, have been acknowledged as significant impediments in the use of CO in gaseous form. ${ }^{6,17}$ CO-releasing molecules (CORMs) have been developed as an alternative CO delivery system allowing a greater ease of administration and control, and potentially enabling a safer, tightly regulated method of low dose CO delivery. These molecules have been extensively studied and their beneficial effects ${ }^{\mathbf{1 8}}$ have been demonstrated in transplant and disease models. ${ }^{19-22} \mathrm{~A}$ large proportion of existing CORMs are based on transition-metal carbonyl complexes $\left[\mathrm{M}_{x} \mathrm{Ly}(\mathrm{CO})_{z}\right.$, where $\mathrm{M}=\mathrm{Mn}, \mathrm{Ru}, \mathrm{Fe}, \mathrm{W}, \mathrm{Mo}$, Cr, Ir or Re]. ${ }^{23-25}$ Early metal carbonyl complexes suffered from low water solubility and high toxicity. The attachment of organic ligands to the metal centre resulted in a newer generation of metal carbonyl complexes, such as CORM- $3,{ }^{26}$ with increased water solubility. However, an issue with metal carbonyl complexes is that the residual by-products (iCORMs) obtained after CO release contain transition metals which is undesirable and could contribute to toxicity. ${ }^{27-29}$

Several CORMs that do not contain transition metals have been reported. ${ }^{30}$ One example is sodium boranocarbonate (CORM-A1), ${ }^{31}$ which is water soluble, capable of liberating CO at $\mathrm{pH} 7.4$ and was found to improve the renal function of rabbit kidney transplants upon reperfusion. ${ }^{32}$ More recent organic 


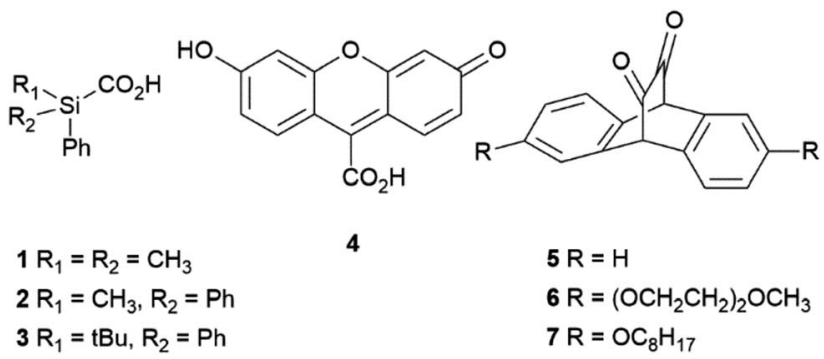

Fig. 1 Selected examples of organic CORMs.

examples (Fig. 1) include the silacarboxylic acids $1-3^{33}$ the fluorescein analogue $4^{34}$ and the cyclic $\alpha$-diketones $5-7 . .^{35}$

Silacarboxylic acids 1-3 have only been employed as a source of $\mathrm{CO}$ gas for carbonylation reactions and require the addition of fluoride-based desilylating reagents to induce CO release. ${ }^{33,36}$ The fluorescein analogue 4 requires exposure to visible light (500 $\mathrm{nm}$ ) for CO release, ${ }^{34}$ while the cyclic $\alpha$-diketones 5-7 need to be encapsulated within pluronic micelles so that photoactivation (400-550 $\mathrm{nm}$ ) can result in effective CO release. However, these examples have yet to show clinical relevance because of issues associated with the mechanism of CO release, solubility and cellular toxicity.

The focus of the current work is the development of organic CORMs that would release CO on physiological stimulus. Furthermore, the formation of an easily characterized organic by-product after $\mathrm{CO}$ release would allow determination of the CO-release kinetics whilst potentially reducing residual compound toxicity. Our approach is based upon the bridged carbonyl compound norbornadien-7-one $(\mathbf{8})^{37}$ which undergoes cheletropic loss of carbon monoxide (CO) giving benzene as a by-product (Fig. 2A).

It is well known that compound $\mathbf{8}$ is remarkably prone to fragmentation with loss of $\mathrm{CO}$ and several computation studies $^{37,39}$ have been carried out on this reaction where the activation energy for this process was calculated to be between 11 to $12 \mathrm{kcal} \mathrm{mol}^{-1}$ with the corresponding rate constant at 300 $\mathrm{K}\left(27^{\circ} \mathrm{C}\right)$ of $4.2 \times 10^{5} \mathrm{~s}^{-1}\left(t_{1 / 2}=1.6 \times 10^{-5} \mathrm{~s}\right)$.

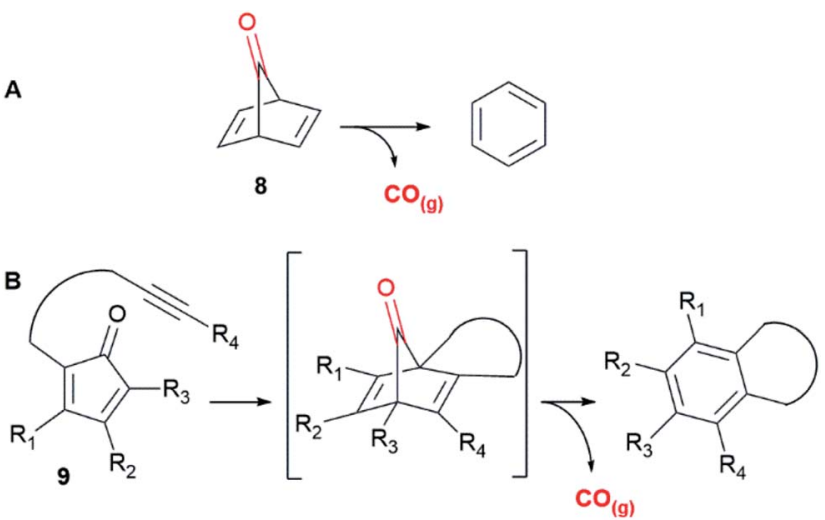

Fig. 2 (A) Cheletropic loss of carbon monoxide from norbornadien-7one (8). (B) Strategy reported by Wang et al. ${ }^{38}$
With this in mind, Wang et al. have recently developed an elegant "click and release" CO prodrug utilising intermolecular Diels-Alder reactions of functionalised tetraphenylcyclopentadienones with strained alkynes to generate unstable norbornadienone intermediates with concomitant loss of $\mathrm{CO} .^{40}$ An intramolecular variant, where the alkyne was tethered to the diene (Fig. 2B, 9) provided a series of CORMs with CO release half-lives, controlled by the rate of the Diels-Alder reaction, ranging from 2 minutes to one week. ${ }^{38}$ These compounds demonstrated possible therapeutic applications in an anti-inflammatory assay and a colitis animal model, however DMSO was required to solubilize them.

We sought an alternative approach where physiological $\mathrm{pH}$ controls the release of CO using bridged carbonyl compounds based upon a norbornenone substructure. These well-known compounds are generally prepared using Diels-Alder reactions of substituted cyclopentadienones and activated dienophiles, such as maleic anhydride, giving stable cycloadducts. Early work on these compounds carried out by Allen et al. ${ }^{\mathbf{4 1}}$ and Fuch et al. ${ }^{\mathbf{2 2 , 4 3}}$ showed that compounds such as 10 could decompose under thermal and/or photochemical conditions to release carbon monoxide (Scheme 1).

However, the conditions for $\mathrm{CO}$ release by heating $\left(200{ }^{\circ} \mathrm{C}\right)^{40}$ or photochemical activation ${ }^{\mathbf{4 2 , 4 3}}$ as reported for $\mathbf{1 0}$ preclude the use of such compounds as CORMs in a biological setting. Given this we have developed a strategy that utilises the properties of both the norbornenone (stability) and norbornadienone (rapid decomposition releasing $\mathrm{CO}$ ) class of compound.

This approach provides a prodrug for an organic CO donor molecule, the general strategy of which utilizes compounds with the functionalised norbornenone structure represented by 12 (Fig. 3). Elimination of $\mathrm{HX}$ would produce the transient norbornadienone which would undergo rapid/spontaneous cheletropic loss of $\mathrm{CO}$ and concomitant aromatisation to byproduct 13. X would be a halogen $(\mathrm{Cl}, \mathrm{Br}$ or $\mathrm{I})$ and $\mathrm{R}_{4}$ an electron withdrawing group. The rate determining step, an E1cB process, would be affected by the substituents $R_{3}$ and $R_{4}$ and thus would control the rate of CO release. This could be achieved when $R_{3} / R_{4}$ was a cyclic imide, which would be less<smiles>CC1=C(c2ccccc2)C(c2ccccc2)=C(C)C1=O</smiles><smiles>O=C1C=CC(=O)O1</smiles>

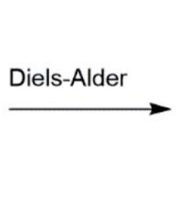<smiles>CC12C(=O)C(C)(C(c3ccccc3)=C1c1ccccc1)C1C(=O)OC(=O)C12</smiles>

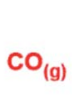

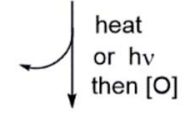<smiles>Cc1c2c(c(-c3ccccc3)c(C)c1-c1ccccc1)C(=O)OC2=O</smiles>

Scheme 1 Formation and aromatisation of cycloadduct 10.41,42 

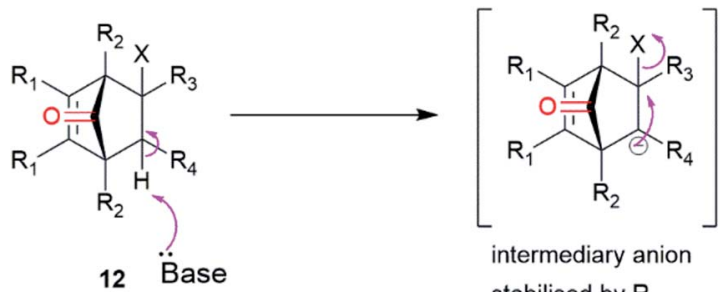

intermediary anion stabilised by $R_{4}$

$$
\downarrow-x^{\ominus}
$$<smiles>[R]c1c([R])c([R])c([R])c([R])c1[R]</smiles><smiles>[R]C1=CC2([R2])C([R])=C([R])C1([R])C([R])=C2[R]</smiles>

norbornadienone intermediate

Fig. 3 Strategy for CO-release from a functionalized norbornen-7one.

susceptible to hydrolysis than an anhydride and also provide a handle for further functionalization. This structural motif would allow the process to be triggered by raising the $\mathrm{pH}$ to give an intermediary anion, stabilized by the imide, followed by loss of halide to give a norbornadienone intermediate.

\section{Discussion}

Einhorn et $a l .{ }^{\mathbf{4 4}}$ reported the synthesis of polyarylphthalimides from the Diels-Alder reaction of tetraarylcyclopentadienones and 2-bromomaleimide in refluxing bromobenzene which occurred with concomitant decarbonylation. Our attempts to carry out the reaction of tetraphenylcyclopentadienone and 2bromo- $N$-phenylmaleimide (14) at lower temperatures in order to isolate the Diels-Alder cycloadduct were unsuccessful due to the slow rate of reaction in refluxing toluene. We surmised that this was due to steric interactions between the 2- and 5- phenyl groups and the bromine substituent of the maleimide.<smiles>O=C1C=C(Br)C(=O)[NH+]1c1ccccc1</smiles><smiles>CC1=C(c2ccccc2)C2(c3ccccc3)C3(C)C(=O)C(C)(C(c4ccccc4)=C3c3ccccc3)C2(C)C(=O)C1=O</smiles><smiles>CC#Cc1ccccc1</smiles><smiles>[134IH]</smiles><smiles>Cc1c([18F])c2c(c(C)c1-c1ccccc1)C(=O)N(c1ccccc1)C2=O</smiles>

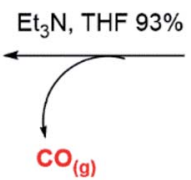<smiles>CC12C(=O)C(Br)(C(c3ccccc3)=C1c1ccccc1)C1(Br)C(=O)N(c3ccccc3)C(=O)C21</smiles>

Scheme 2 Synthesis and decarbonylation of CORM 16.
Pleasingly, the less sterically-encumbered 2,5-dimethyl-3,4diphenylcyclopentadienone (15), which exists as a reversible dimer, reacted smoothly with 14 to give endo-16 in $71 \%$ yield after crystallisation from diethyl ether (Scheme 2). To test whether this compound could release $\mathrm{CO}$ it was treated with triethylamine in THF. Effervescence occurred and phthalimide 17 was isolated in 93\% yield. GC/MS headspace analysis of a solution of 16 in DMSO in a sealed tube after treatment with DBU confirmed that the gas released was CO. ${ }^{1} \mathrm{H}$ NMR analysis of the solution indicated the complete conversion of 16 into 17.

With the proof of principle that cycloadducts like 16 can release $\mathrm{CO}$ on treatment with base, attention turned towards making water soluble analogues. To this end a series of CORMs functionalized with amine salts were prepared. Maleimide 18, ${ }^{\mathbf{4 5}}$ with a pendant activated ester was reacted with mono-Boc protected ethylene diamine giving 19 which was subjected to a bromination-dehydrobromination sequence to give bromomaleimide 20 in 57\% yield over the two steps (Scheme 3). Cycloaddition of diene $\mathbf{1 5}$ and 20 gave adduct 21 as a $3: 1$ mixture of endo and exo-isomers in 93\% yield. Adduct 21 was
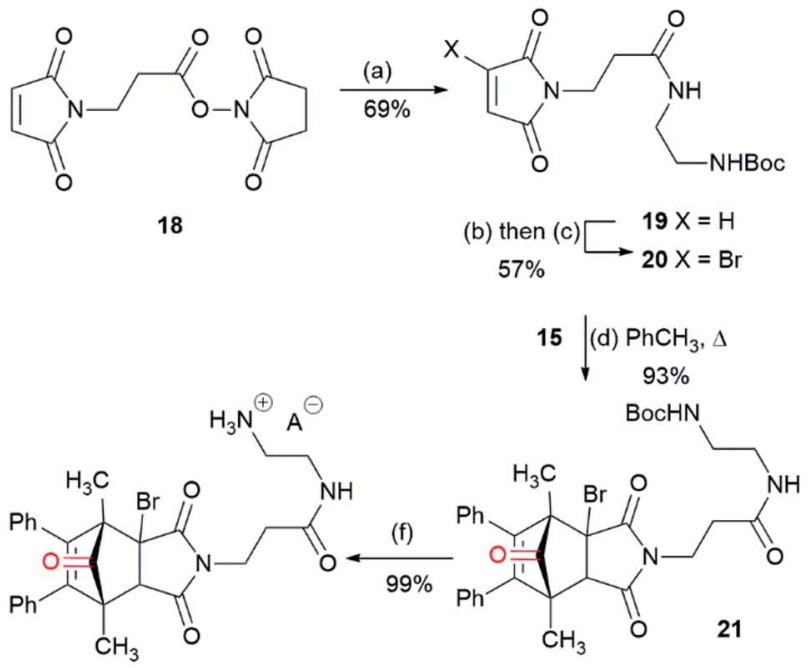

ocom-19

$A^{-}=\mathrm{Cl}^{-}, 99 \%(3: 1$ endo:exo)

$A^{-}=$TFA $^{-}, 34 \%(10: 1$ endo:exo $)$

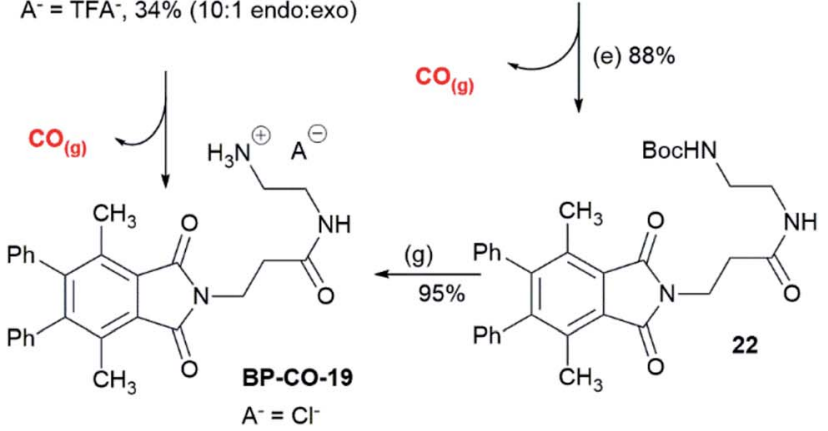

Scheme 3 Synthesis of oCOm-19 reagents and conditions: (a) BocNHCH $\mathrm{CH}_{2} \mathrm{NH}_{2}, \mathrm{CH}_{2} \mathrm{Cl}_{2}, \mathrm{O}^{\circ} \mathrm{C}$ to rt (69\%). (b) $\mathrm{Br}_{2}, \mathrm{CCl}_{4}$, reflux. (c) $\mathrm{NEt}_{3}, \mathrm{THF}, \mathrm{O}{ }^{\circ} \mathrm{C}$ (57\% over two steps). (d) $\mathrm{PhCH}_{3}, 15$, reflux, (93\%). (e) DBU, THF, rt, (88\%). (f) $6 \mathrm{M} \mathrm{HCl}, 1,4$-dioxane, $0{ }^{\circ} \mathrm{C}$ to $\mathrm{rt}, \mathrm{A}^{-}=\mathrm{Cl}^{-}(99 \%)$, $\mathrm{A}^{-}=\mathrm{TFA}^{-},(34 \%+$ inseparable mixture of oCOM-19 and BP-CO-19). (g) $6 \mathrm{M} \mathrm{HCl}, 1,4$-dioxane, $0{ }^{\circ} \mathrm{C}$ to $\mathrm{rt}$, (95\%). 
sensitive to base and on treatment with DBU in THF gave phthalimide 22 (88\%). Removal of the Boc-group of adduct 21 was achieved on reaction with $6 \mathrm{M} \mathrm{HCl}$ in dioxane to give oCOm19 as its $\mathrm{HCl}$ salt (99\%, 3 : 1 mixture of endo and exo isomers). In a separate reaction, the reaction product was subjected to reverse phase chromatography on a $\mathrm{C}-18$ solid phase extraction cartridge using $1 \%$ aqueous TFA and acetonitrile which resulted in partial separation of the endo- and exo-isomers (10:1, 34\%) of oCOm-19 as the TFA salt, with the remainder of the material as a mixture of OCOm-19 and aromatised product, iCORM BPCO-19. The latter compound was also prepared in $95 \%$ yield by treatment of 22 with $6 \mathrm{M} \mathrm{HCl}$ in dioxane.

Using a similar process ethylenediamine and diethylenetriamine derived CORMs were prepared from carboethoxymaleimide 23 (Scheme 4).

Reaction of bromomaleimide 26 with diene dimer 15 gave cycloadduct 28 (endo : exo $=2.5: 1$ ) in $84 \%$ yield after purification by column chromatography. Partial separation was achieved with a sample of endo-28 isolated in $32 \%$ yield with the remaining $52 \%$ a $1: 1$ mixture of endo- and exo-isomers. Similarly, reaction of bromomaleimide 27 with 15 gave a $3: 1$ mixture of endo- and exo-adducts 29 which after column chromatography afforded the endo-isomer (60\%) along with a mixture of the isomers in $27 \%$ yield. Removal of the Bocprotecting groups of endo-28 and -29 was achieved on treatment with $6 \mathrm{M} \mathrm{HCl}$ in dioxane and gave, after purification on reverse-phase solid-phase cartridges and lyophilization, oCOm-
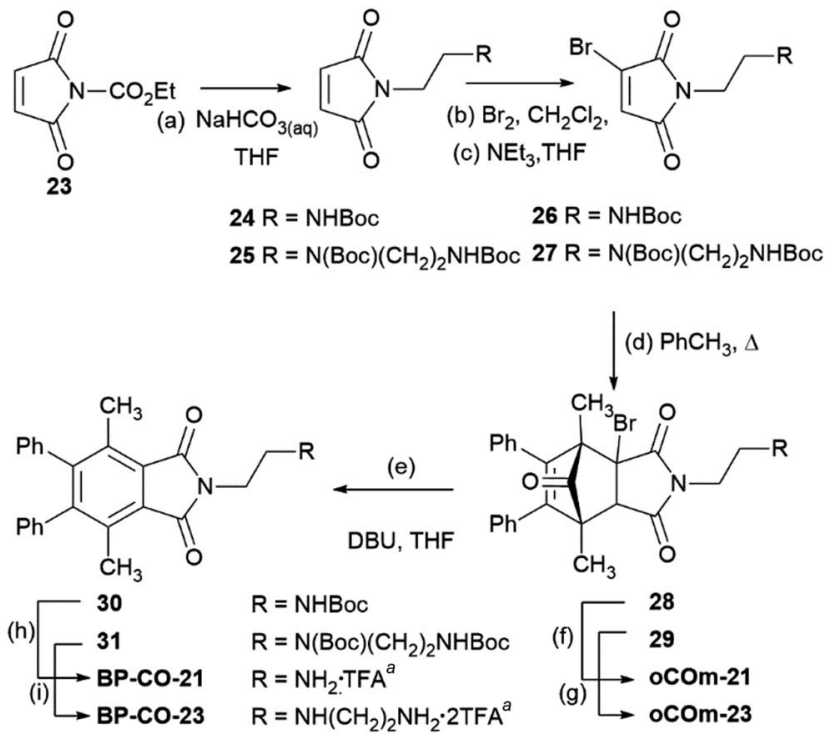

Scheme 4 Synthesis of oCOm-21 and -23 . Reagents and conditions: (a) BocNH $\left(\mathrm{CH}_{2}\right)_{2} \mathrm{NH}_{2}, \mathrm{THF}, \mathrm{H}_{2} \mathrm{O}, 0{ }^{\circ} \mathrm{C}$ to rt, $24(58 \%)$; $\mathrm{BocNH}\left(\mathrm{CH}_{2}\right)_{2}-$ $\mathrm{NBoc}\left(\mathrm{CH}_{2}\right)_{2} \mathrm{NH}_{2}, \mathrm{THF}, \mathrm{H}_{2} \mathrm{O}, 0{ }^{\circ} \mathrm{C}$ to $\mathrm{rt}, 25$ (mixture with ethyl carbamate). (b) $\mathrm{Br}_{2}, \mathrm{CCl}_{4}$, reflux. (c) $\mathrm{NEt}_{3}, \mathrm{THF}, 0{ }^{\circ} \mathrm{C}, 26$ (73\% over two steps), 27 (25\% over two steps $+1: 1$ inseparable mixture of 27 and ethyl carbamate). (d) $\mathrm{PhCH}_{3}, 15$, reflux, 28 (84\% $2.5: 1$ endo : exo), 29 (60\% endo) (e) DBU, THF, rt, 30 (61\%), 31 (76)\%. (f) and (g) $6 \mathrm{M} \mathrm{HCl}, 1,4-$ dioxane, $0{ }^{\circ} \mathrm{C}$ to rt, oCOM-21 (63\%), oCOM-23 (63\%). (h) $6 \mathrm{M} \mathrm{HCl}, 1,4-$ dioxane, $0{ }^{\circ} \mathrm{C}$ to $\mathrm{rt}(78 \%)$. (i) $6 \mathrm{M} \mathrm{HCl}, 1,4$-dioxane, rt to $50{ }^{\circ} \mathrm{C}(82 \%)$. ${ }^{a}$ Purified by reverse phase $\mathrm{C}-18$ solid phase extraction cartridge using $1 \%$ aqueous TFA and acetonitrile.

21 and -23 both in 63\% yield as their mono- and bistrifluoroacetate salts as white powders. Aromatisation of $\mathbf{2 8}$ and 29 on treatment with DBU gave phthalimides 30 and 31 and subsequent removal of the Boc-group provided the respective iCORMs BP-CO-21 and BP-CO-23 in 48 and 62\% yield respectively over the two steps. A series of desbromo-analogues of oCOm-19, -21 and -23, DB-CO-19, -21 and -23 respectively, which lack the ability to release $\mathrm{CO}$ under physiological conditions, were also synthesised by Diels-Alder reactions of diene 15 and maleimides 19, 24, and 25 and subsequent deprotection of the Boc groups for use as control compounds (Scheme S1, ESI $\dagger$ ).

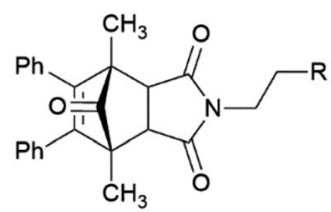

DB-CO-19 R = $\mathrm{CONH}\left(\mathrm{CH}_{2}\right)_{2} \mathrm{NH}_{2} \cdot$ TFA DB-CO-21 $\mathrm{R}=\mathrm{NH}_{2} \cdot \mathrm{TFA}$ DB-CO-23 $\mathrm{R}=\mathrm{NH}\left(\mathrm{CH}_{2}\right)_{2} \mathrm{NH}_{2} \cdot 2$ TFA

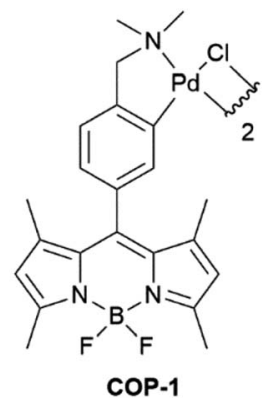

To assess whether CORMs oCOm-19, -21 and -23 have therapeutic potential their water solubility and $\mathrm{CO}$ release profiles were measured at $\mathrm{pH}$ 7.4. Pleasingly all three were soluble in tissue culture water at $20{ }^{\circ} \mathrm{C}$ at $3.2,10.8$ and $18.2 \mathrm{mg} \mathrm{mL}^{-1}$ respectively. Transplant organ preservation solutions are normally maintained at $8{ }^{\circ} \mathrm{C}$. Unfortunately, the solubility of oCOm-19 at $8{ }^{\circ} \mathrm{C}$ was low and could not be determined, whereas those lacking the amide linking group, oCOm-21 and -23, were measured as 3.9 and $17.6 \mathrm{mg} \mathrm{mL}^{-1}$ respectively. The CO release profiles for the more soluble CORMs oCOm-21 and -23 were assessed by monitoring the formation of the corresponding iCORMs, BP-CO-21 and BP-CO-23 in TRIS-sucrose buffer at $\mathrm{pH}$ 7.4 using an HPLC method. oCOm-21 showed half-lives for CO release of $19 \mathrm{~min}$ at $37^{\circ} \mathrm{C}$ (Fig. S1, ESI $\dagger$ ) and $31 \mathrm{~h}$ at 4 to $5{ }^{\circ} \mathrm{C}$. oCOm-23 half-lives at the same temperatures were $75 \mathrm{~min}$ and $32 \mathrm{~h}$, respectively. The $\mathrm{CO}$ release was also supported by monitoring via a CO-selective electrode over a range of $\mathrm{pH}$ and myoglobin assays (Fig. S2a to c, ESI $\dagger$ ). There was no sign of the formation of the corresponding iCORMs from solutions of oCOm-19, -21 and -23 in aqueous media at $\mathrm{pH}<7$ after prolonged periods of time ( $>1$ week). Samples showed no deterioration after being left at room temperature exposed to ambient light for over one month. The thermal stability of oCOM-21 was investigated by thermogravimetric analysis and was shown to undergo decomposition at $125{ }^{\circ} \mathrm{C}$ (Fig. S3a, ESI $\dagger$ ). Further analysis showed that heating a sample of oCOM-21 to $90{ }^{\circ} \mathrm{C}$ and holding it at that temperature for $30 \mathrm{~min}$ resulted in a $4 \%$ loss of mass (Fig. S3b, ESI $\dagger$ ). HPLC analysis of this sample showed that it was a $96: 4$ mixture of oCOm-21 and its corresponding iCORM (Fig. S3c, ESI $\dagger$ ).

In context to applications such as organ transplantation, the toxicity of oCOm-19, -21 and -23 was assessed using sensitive MDCK cells at $37{ }^{\circ} \mathrm{C}$ and $\mathrm{EC}_{50}$ values were measured as 86, 11.2 and 10.1 $\mu \mathrm{M}$, respectively (Fig. S4, ESI $\dagger$ ). iCORMs BP-CO-21 and 

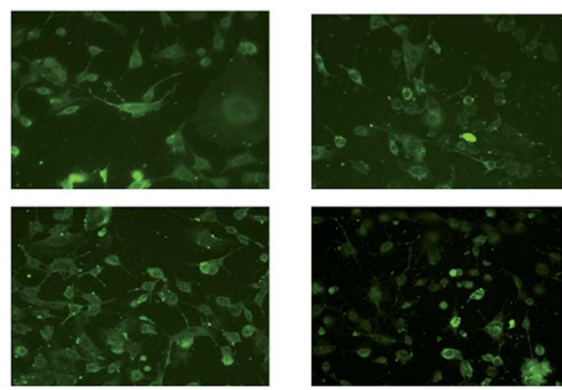

$10 \mu \mathrm{M}$ oCOm-21 top $8^{\circ} \mathrm{C}$ bottom $37^{\circ} \mathrm{C}$
$10 \mu \mathrm{M}$ oCOm-23 top $8^{\circ} \mathrm{C}$, bottom $37^{\circ} \mathrm{C}$

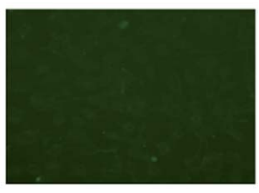

(a)

(i)

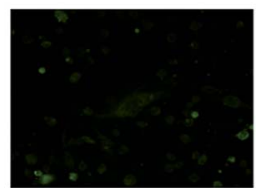

top $50 \mu \mathrm{M}$ BP-CO-21 bottom $50 \mu \mathrm{M}$ BP-CO-23 both at $37^{\circ} \mathrm{C}$
Fig. 4 CO specific fluorescent probe (COP-1) confirms increased intracellular $\mathrm{CO}$ levels following exposure to oCOm-21 (10 $\mu \mathrm{M})$ or oCOm-23 $(10 \mu \mathrm{M})$ against the respective iCORM $(50 \mu \mathrm{M})$ at both $37^{\circ} \mathrm{C}$ and $8{ }^{\circ} \mathrm{C}$.
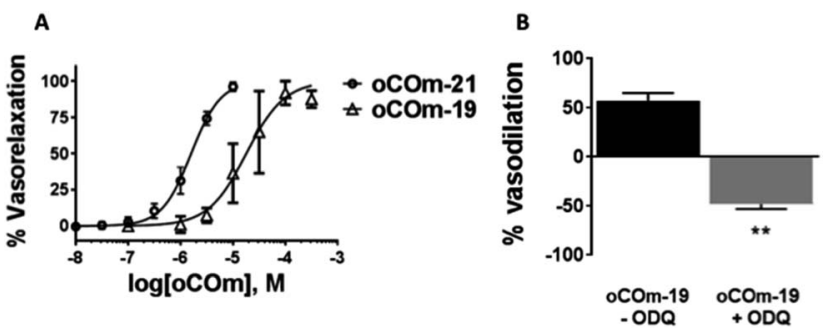

Fig. 5 Vasorelaxant effect of oCOm-19 and -21 in isolated rat aortas at $37^{\circ} \mathrm{C}$. (A) Relaxation responses in precontracted aortic rings expressed as a percent change of the contractile response to phenylephrine (100 nM). (B) Responses to $\mathrm{EC}_{50}$ concentrations of oCOm-19 repeated in the presence of the guanylate cyclase inhibitor ODQ. Data was analysed using a One-way ANOVA with Bonferroni post-hoc test and expressed as mean \pm SEM. ** denotes $P<0.01=v$ s. the non $(-)-O D Q$ inhibited group.

-23 gave $\mathrm{EC}_{50}$ values of 21 and $100 \mu \mathrm{M}$, respectively. The toxicity of oCOm-21 was also measured against this cell line at $8{ }^{\circ} \mathrm{C}$ and gave an $\mathrm{EC}_{50}>100 \mu \mathrm{M}$.

CO delivery to MDCK cells by $\mathbf{O C O m}-21$ and -23 at 8 and $37^{\circ} \mathrm{C}$ was confirmed using the CO-selective fluorescent probe COP-1 developed by Chang et al. ${ }^{\mathbf{4 6}}$ (Fig. 4).

Oral bioavailability in rats was demonstrated by carboxyhaemoglobin analysis following administration of oCOm-19 and $\mathbf{- 2 1}$ by oral gavage. Moderate but significant increases in carboxyhaemoglobin levels in the plasma were obtained after $3 \mathrm{~h}$ of administration for the less soluble oCOm-19 and within $1 \mathrm{~h}$ for oCOm-21 (Table S1, ESI $\dagger$ ). BP-CO-19, which cannot release $\mathrm{CO}$, showed no increase in carboxyhaemoglobin at the same time points.

CO relaxes vascular tissues by acting on the cGMP pathway and high conductance calcium-activated $\mathrm{K}^{+}\left(\mathrm{K}_{\mathrm{Ca}}\right)$ channels. To assess the vasorelaxant effect of our compounds, pre-contracted rat aortic rings were treated with oCOm-19 and -21. A dosedependent relationship was observed for both compounds with $\mathrm{EC}_{50}$ values of $18.0 \pm 0.8 \mu \mathrm{M}$ and $1.6 \pm 0.9 \mu \mathrm{M}$ respectively (Fig. 5). This vasodilatory effect was reversed by the addition of $1 H$ - $(1,2,4)$ oxadiazolo[4,3-a]quinoxalin-1-one (ODQ), an inhibitor of soluble guanylate cyclase (sGC).

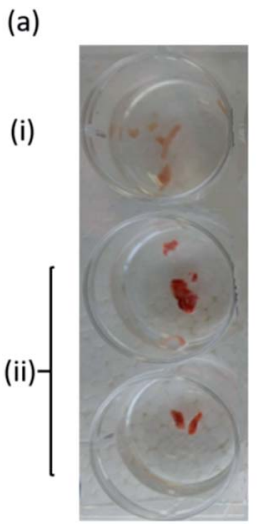

(b)

(i)

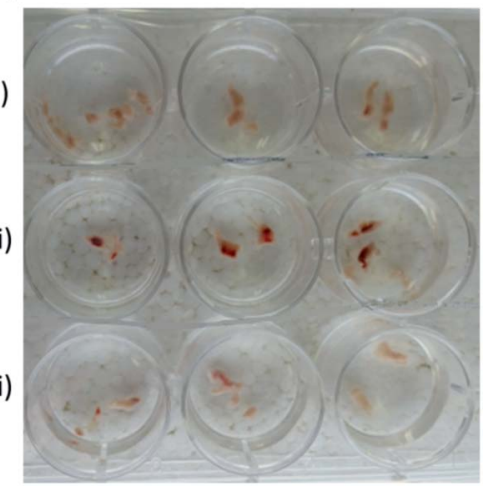

Fig. 6 Protective effect of oCOm-21 on heart tissue (rat myocardium): (a) fresh heart tissue samples (i) untreated and not stained (ii) untreated and stained with TTC stain; (b) heart tissue samples after 48 hours incubation (i) control heart tissue samples stained with TTC stain (ii) heart tissue samples incubated with oCOm-21 (3 $\mu \mathrm{M})$ after 48 hours and stained with TTC stain (iii) heart tissue samples incubated with DBCO-21 $(3 \mu \mathrm{M})$ after 48 hours and stained with TTC stain.

In a preliminary experiment, the preservation of tissue viability was demonstrated for rat myocardium. Tissue samples treated with oCOm-21 stored in Dulbecco's modified Eagle medium appeared to be more viable after $48 \mathrm{~h}$ compared to an untreated control based upon dehydrogenase activity indicated by conversion of tetrazolium chloride (TTC, white) into the corresponding formazan (red) (Fig. 6).

\section{Conclusions}

In conclusion, we have developed CO prodrugs based upon norbornenones which function via $\mathrm{E} 1 \mathrm{cB}$ elimination of $\mathrm{HBr}$ under physiological conditions, producing a reactive norbornadienone intermediate that rapidly undergoes chelotropic loss of CO. The three prodrugs, oCOm-19, $\mathbf{- 2 1}$, and $\mathbf{- 2 3}$ are thermally stable solids that show good water solubilities and CO release profiles. Under physiological conditions they have been shown to deliver CO to cells, have a vasorelaxant effect and have the potential to preserve tissue sample viability. We are developing new generations of these compounds and investigating their applications as additives for organ transplantation preservation solutions.

\section{Acknowledgements}

This work is supported by a University of Otago Research Grant and by the Ministry of Business, Innovation and Employment grant (CONT-29537-HVMSSI-UOO).

\section{Notes and references}

1 I. A. Sammut, R. Foresti, J. E. Clark, D. J. Exon, M. J. J. Vesely, P. Sarathchandra, C. J. Green and R. Motterlini, Br. J. Pharmacol., 1998, 125, 1437-1444. 
2 A. Ayer, A. Zarjou, A. Agarwal and R. Stocker, Physiol. Rev., 2016, 96, 1449-1508.

3 A. Bagul, S. A. Hosgood, M. Kaushik and M. L. Nicholson, Transplantation, 2008, 85, 576-581.

4 I. C. Winburn, J. C. Harrison, R. J. MacGinley, R. J. Walker and I. A. Sammut, Transplantation, 2006, 82, 1043.

5 S. Ghosh, J. Gal and N. Marczin, Ann. Med., 2010, 42, 1-12. 6 S. W. Ryter and L. E. Otterbein, BioEssays, 2004, 26, 270-280.

7 L. E. Otterbein, F. H. Bach, J. Alam, M. Soares, L. H. Tao, M. Wysk, R. J. Davis, R. A. Flavell and A. M. Choi, Nat. Med., 2000, 6, 422-428.

8 Y. Ruan, L. Wang, Y. Zhao, Y. Yao, S. Chen, J. Li, H. Guo, C. Ming, S. Chen, F. Gong and G. Chen, Kidney Int., 2014, 86, 525-537.

9 M. Bilban, A. Haschemi, B. Wegiel, B. Y. Chin, O. Wagner and L. E. Otterbein, J. Mol. Med., 2008, 86, 267-279.

10 S. Brouard, L. E. Otterbein, J. Anrather, E. Tobiasch, F. H. Bach, A. M. Choi and M. P. Soares, J. Exp. Med., 2000, 192, 1015-1026.

11 N. Hill-Kapturczak and A. Agarwal, Am. J. Physiol. Renal. Physiol., 2006, 290, F787-F788.

12 S. W. Ryter, J. Alam and A. M. Choi, Physiol. Rev., 2006, 86, 583-650.

13 J. J. Freiberger, CO as a Stimulant for Mitochondrial Biogenesis in Human Cardiac Muscle, ClinicalTrials.gov Bethesda (MD): National Library of Medicine, US, 2012, https:// clinicaltrials.gov/ct2/show/NCT01727167.

14 Mallinckrodt Pharmaceuticals, Safety and Tolerability Study of Inhaled Carbon Monoxide in Kidney Transplant Patients, ClinicalTrials.gov Bethesda (MD): National Library of Medicine, US, 2007, https://clinicaltrials.gov/ct2/show/ NCT00531856.

15 E. Bathoorn, D. J. Slebos, D. S. Postma, G. H. Koeter, A. J. van Oosterhout, M. van der Toorn, H. M. Boezen and H. A. Kerstjens, Eur. Respir. J., 2007, 30, 1131-1137.

16 H. H. Usansky and K. Jamil, Dosing regimes and methods of treatment using carbon monoxide, US 2011/0280966, 5/12/ 2011, 1911.

17 S. R. Thom, L. K. Weaver and N. B. Hampson, Am. J. Respir. Crit. Care Med., 2005, 171, 1318.

18 C. Steiger, C. Hermann and L. Meinel, Eur. J. Pharm. Biopharm., 2016, DOI: 10.1016/j.ejpb.2016.11.002, ahead of print.

19 A. Vannacci, C. Marzocca, L. Giannini, L. Mazzetti, S. Franchi-Micheli, P. Failli, E. Masini, R. Motterlini and P. F. Mannaioni, Inflammation Res., 2006, 55, S05-S06.

20 Y. Caumartin, J. Stephen, J. P. Deng, D. Lian, Z. Lan, W. Liu, B. Garcia, A. M. Jevnikar, H. Wang, G. Cepinskas and P. P. Luke, Kidney Int., 2011, 79, 1080-1089.

21 A. Sener, K. C. Tran, J. P. Deng, B. Garcia, Z. Lan, W. Liu, T. Sun, J. Arp, M. Salna, P. Acott, G. Cepinskas, A. M. Jevnikar and P. P. Luke, J. Urol., 2013, 190, 772-778.

22 M. D. Pizarro, J. V. Rodriguez, M. E. Mamprin, B. J. Fuller, B. E. Mann, R. Motterlini and E. E. Guibert, Cryobiology, 2009, 58, 248-255.
23 S. H. Heinemann, T. Hoshi, M. Westerhausen and A. Schiller, Chem. Commun., 2014, 50, 3644-3660.

24 R. Motterlini and L. E. Otterbein, Nat. Rev. Drug Discovery, 2010, 9, 728-743.

25 A. C. Kautz, P. C. Kunz and C. Janiak, Dalton Trans., 2016, 45, 18045-18063.

26 J. E. Clark, P. Naughton, S. Shurey, C. J. Green, T. R. Johnson, B. E. Mann, R. Foresti and R. Motterlini, Circ. Res., 2003, 93, e2-e8.

27 M. Vadori, M. Seveso, F. Besenzon, E. Bosio, E. Tognato, F. Fante, M. Boldrin, S. Gavasso, L. Ravarotto, B. E. Mann, P. Simioni, E. Ancona, R. Motterlini and E. Cozzi, Xenotransplantation, 2009, 16, 99-114.

28 I. C. Winburn, K. Gunatunga, R. D. McKernan, R. J. Walker, I. A. Sammut and J. C. Harrison, Basic Clin. Pharmacol. Toxicol., 2012, 111, 31-41.

29 S. Romanski, E. Stamellou, J. T. Jaraba, D. Storz, B. K. Kramer, M. Hafner, S. Amslinger, H. G. Schmalz and B. A. Yard, Free Radical Biol. Med., 2013, 65, 78-88.

$30 \mathrm{~S}$. H. Heinemann, T. Hoshi, M. Westerhausen and A. Schiller, Chem. Commun., 2014, 50, 3644-3660.

31 R. Motterlini, P. Sawle, S. Bains, J. Hammad, R. Alberto, R. Foresti and C. J. Green, FASEB J., 2005, 19, 284-286.

32 A. Sandouka, B. J. Fuller, B. E. Mann, C. J. Green, R. Foresti and R. Motterlini, Kidney Int., 2006, 69, 239-247.

33 S. D. Friis, R. H. Taaning, A. T. Lindhardt and T. Skrydstrup, J. Am. Chem. Soc., 2011, 133, 18114-18117.

34 L. A. P. Antony, T. Slanina, P. Sebej, T. Solomek and P. Klan, Org. Lett., 2013, 15, 4552-4555.

35 P. Peng, C. Wang, Z. Shi, V. K. Johns, L. Ma, J. Oyer, A. Copik, R. Igarashi and Y. Liao, Org. Biomol. Chem., 2013, 11, 66716674.

36 S. D. Friis, T. Skrydstrup and S. L. Buchwald, Org. Lett., 2014, 16, 4296-4299.

37 J. Zhang, D. M. Ho and R. A. Pascal Jr, J. Am. Chem. Soc., 2001, 123, 10919-10926.

38 X. Ji, C. Zhou, K. Ji, R. E. Aghoghovbia, Z. Pan, V. Chittavong, B. Ke and B. Wang, Angew. Chem., Int. Ed., 2016, 55, 1584615851.

39 C.-H. Lai, E. Y. Li, K.-Y. Chen, T. J. Chow and P.-T. Chou, J. Chem. Theory Comput., 2006, 2, 1078-1084.

40 D. Wang, E. Viennois, K. Ji, K. Damera, A. Draganov, Y. Zheng, C. Dai, D. Merlin and B. Wang, Chem. Commun., 2014, 50, 15890-15893.

41 C. F. H. Allen and J. Van Allan, J. Am. Chem. Soc., 1942, 64, 1260-1267.

42 B. Fuchs, J. Chem. Soc. C, 1968, 68-71, DOI: 10.1039/ j39680000068.

43 B. Fuchs and G. Scharf, J. Org. Chem., 1981, 46, 5395-5398. 44 R. Vanel, F. Berthiol, B. Bessieres, C. Einhorn and J. Einhorn, Synlett, 2011, 1293-1295.

45 Y.-C. Su, Y.-L. Lo, C.-C. Hwang, L.-F. Wang, M. H. Wu, E.-C. Wang, Y.-M. Wang and T.-P. Wang, Org. Biomol. Chem., 2014, 12, 6624-6633.

46 B. W. Michel, A. R. Lippert and C. J. Chang, J. Am. Chem. Soc., 2012, 134, 15668-15671. 